\title{
FOSSILIFEROUS BOULDERS OF LOWER CAMBRIAN PHOSPHORITIC SANDSTONE IN SOUTHWESTERN FINLAND
}

\author{
JYRKI J. LEHTOVAARA and RISTO TYNNI
}

\begin{abstract}
LEHTOVAARA, JYRKI J. and TYNNI, RISTO 1983: Fossiliferous boulders of Lower Cambrian phosphoritic sandstone in southwestern Finland. Bull. Geol. Soc. Finland 55, 2, 85-99.

The paper deals with fossiliferous sandstone boulders from three localities in southwestern Finland. The largest of the boulders was found on the west coast west of Olkiluoto. It is conglomeratic with an abundance of worn remains of lingulid and obolellid brachiopod valves. Its rock type is made up of a relatively coarse, bimodal quartz sandstone containing a few phosphoritic siltstone fragments. The main part is sandy and practically free of glauconite, which is more common in the phosphoritic fragments.

A few of the phosphoritic pieces are tubular in form having phosphorite enriched in an outer ring and a one-grain-thick outermost crust of quartz. They may be worn remains of Hyolithellus micans. Some of the brachiopod shells contain small calcitic globules in a carbonaceous phosphorite matrix.

Tasmanites sp. is one of the few preserved forms of the Acritarch genera.

According to the fossils, the sandstone dates to the upper part of the Lower Cambrian, corresponding to the Lingulid sandstone facies in Västergötland, which in turn corresponds to the Holmia kjerulfi-group Zone in southern Scandinavia. Mineralogically and petrologically, too, the rock could be derived from such lithostratigraphical units. Sandstones of the same age have not been reported previously from Finland. The present boulders would seem to derive from the bottom of the Bothnian Sea.

Although smaller and not so conglomeratic the boulders from Säkylä and Uusikaupunki are fossiliferous.

The fossil fragments in the boulder from Pyhäjärvi, Säkylä, are probably remains of the brachiopod Mickwitzia, and thus refer to a Lower Cambrian stratum still older than the former. The worn brachiopod fragments in the boulder from North Viisastenkari, Uusikaupunki, did not allow the boulder to be dated more accurately within the Lower Cambrian.
\end{abstract}

Key words: fossils, sandstone, Lower Cambrian.

Jyrki J. Lehtovaara: Institute of Geology and Mineralogy, University of Turku, SF-20500 Turku 50, Finland.

Risto Tynni: Geological Survey of Finland, Kivimiehentie 1, SF-02150 Espoo 15, Finland.

\section{Discovery}

Glacial boulders of Cambrian sandstone have long been found sporadically in south- western Finland, in particular on the coastal shores (see e.g. Lehtovaara 1982a), but they rarely contain fossils. Impetus to the present study was given by a spectacularly fossili- 


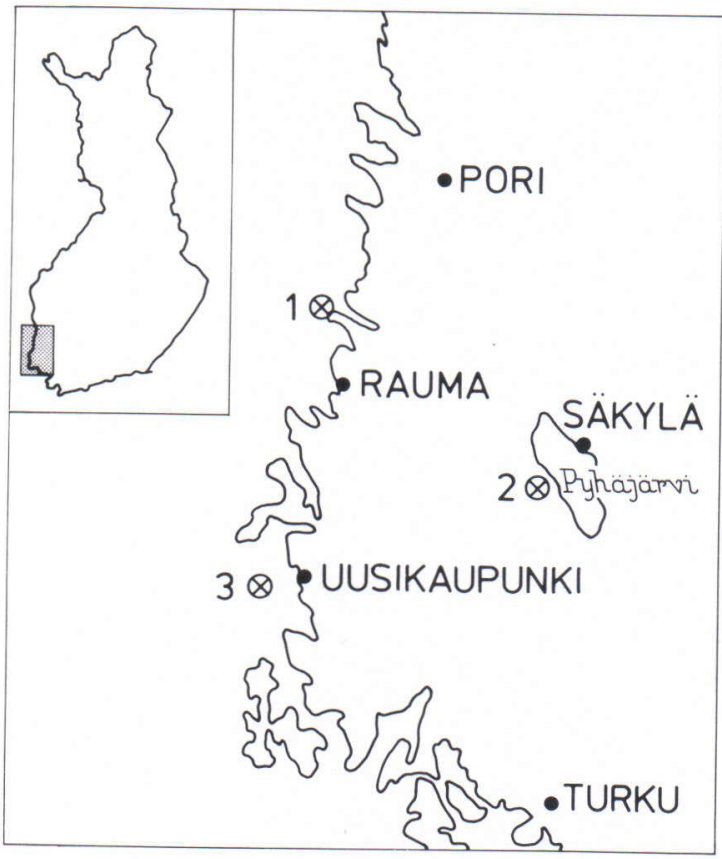

Fig. 1. The places where the boulders were found, 1. The western side of Olkiluoto 2. The southern side of Sieravuori 3. The northern Viisastenkari, the western side of Uusikaupunki.

ferous boulder of conglomeratic sandstone delivered to the Institute of Geology and Mineralogy of the University of Turku by Mr. Matti Tirronen. The boulder was found while a beacon was being constructed on
Iso Susikari, an islet two kilometres west of Olkiluoto headland on the west coast (Fig. 1). The finders searched for other boulders of similar appearance but without success.

The lithology of this sample was studied by Jyrki Lehtovaara and the fossils by Risto Tynni. Two other fossiliferous boulders are also discussed by Risto Tynni.

\section{Rock data}

\section{Boulder 1. found west of Olkiluoto}

Mineralogy and petrology

This boulder is flat, measuring $23 \times 16 \times$ $5 \mathrm{~cm}^{3}$ (Fig. 2A). It is worn and rounded but one of the big, flat surfaces is rather freshly broken and displays the fossil contents very clearly (visible in Fig. 2B).

The original colour of the rock was light grey but it is now covered with uneven rusting. The few larger clastic rock fragments, 2-4 cm in length, are mainly flat and dark brown in colour. The abundance of fossils adds to the conglomeratic character of the rock. Most of the fossils consist of worn shells of greyish brown or deep blue brachiopods one centimetre long (in more detail in Figs. $3 \mathrm{~A}-\mathrm{B}$ ). The impressions of shells are strongly rusty. There also are a few tubular
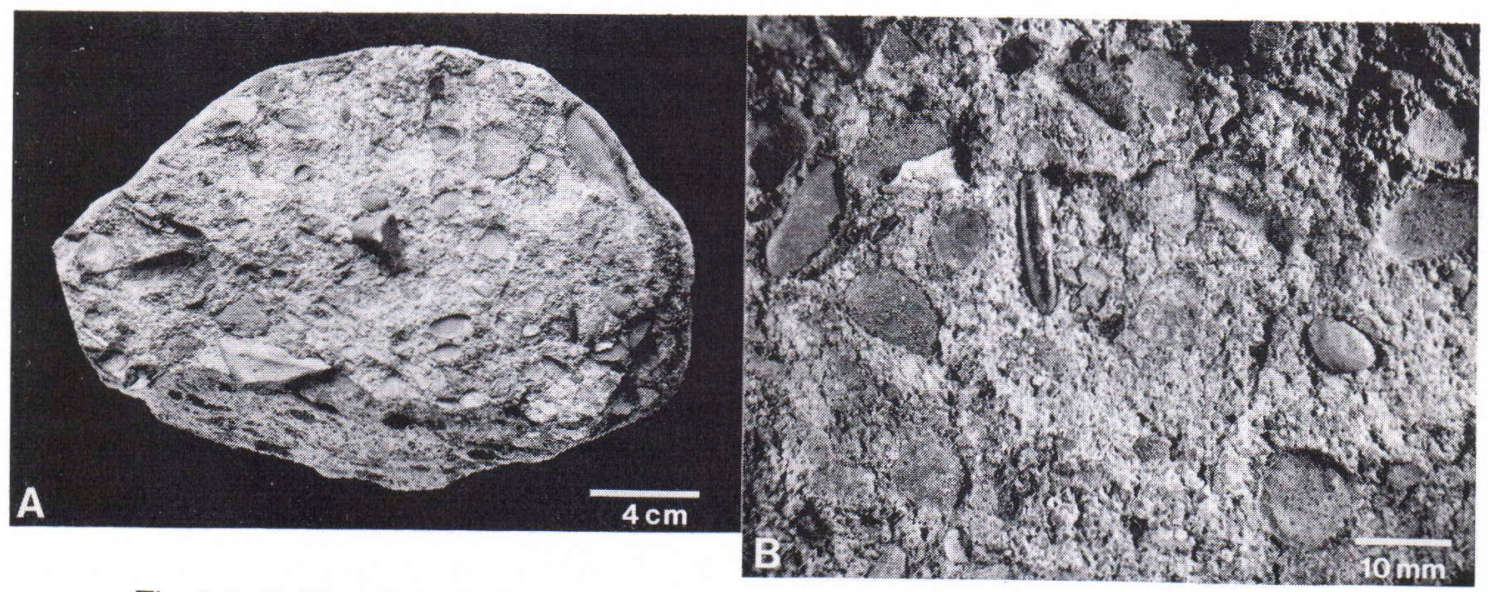

Fig. 2 A, B The phosporitic boulder of sandstone from the western side of Olkiluoto. 
pieces, up to some $\mathrm{cm}$ in length, $0.5 \mathrm{~cm}$ in diameter, and dark brown in colour (Fig. 6 A).

The coarser rock fragments and fossils have a macroscopic orientation along the bedding plane whereas their distribution is rather homogeneous, and the sandstone boulder consists of only one layer. Seen microscopically, the rock has a weakly developed laminated structure caused by alternating grain sizes of the quartz particles. The sand material is generally coarse and has a bimodal grain size distribution consisting of coarser quartz grains, $0.5-1.5 \mathrm{~mm}$ in diameter, and, in some laminations, finer matrix grains, $0.1-0.3 \mathrm{~mm}$ in diameter. The roundness of the grains is well developed. In comparison with other relatively adjacent Cambrian deposits of the Bothnian Sea region, from Aland (Simonen and Kouvo 1955), the western shoals of the Bothnian Sea (Thorslund and Axberg 1979) and Söderfjärden, Vaasa (Lehtovaara 1982b), it appears that the sandy material of the Olkiluoto boulder represents the very coarsest fractions that settled in the commonly fine-grained Cambrian clastic layers.

Mineralogically the rock is an orthoquartzite made up almost totally of quartz. The quality of the quartz grains is very heterogeneous, differences being large in the amount and quality of inclusions and deformation of the particles. Some composite quartz grains also occur. Consequently, several source rocks must have been delivering to this deposit. A few detrital grains of feldspar and zircon, also rounded, and sparse glauconitized particles have been found. Authigenic overgrowth of quartz together with precipitation of calcite have cemented the rock, and no empty pore space is visible. Some tourmaline has also been generated. A secondary diffuse film of rust occurs between many of the quartz particles with some developed goethite crystals. Thus, in a mineralogical sense, the rock is distinguished mainly by its high content of quartz.

The flat rock fragments consist of more angular grains of silt to fine sand sizes with a dense matrix impregnated with pale brown phosphoritic material. They also contain more grains of glauconitized character.

A cross section of one of the tubular pieces (Fig. 6B) shows a concentric structure consisting of a large centre composed of siltsized quartz in a phosphoritic matrix that extends outwards to form a phosphorite outer ring almost devoid of larger grains. The outermost »crust» consists of a onegrain layer of separate quartz particles in the phosphoritic matrix. This kind of structure could have been formed inorganically but, on the other hand, it has a rather organized construction (discussed further in fossil data). In another tube, this phosphoritic matrix occurs only in the outer ring, the centre consisting of euhedric carbonate crystals. Nowadays, all the tubular pieces are aligned parallel to the bedding plane, not for example perpendicular to it.

The most characteristic feature of this sample is the abundancy of shells of brachiopod fossils. The deep blue surface of many of them is caused by secondary vivianite. As far as can be deduced from thin sections, the amount of phosphorite varies in the shells. These contain small globules (as pores of Figs. 5A-D), $0.05 \mathrm{~mm}$ in diameter, which seem to be enveloped in a narrow, empty aureole surrounded, in turn, by phosphorite enriched in black carbonaceous material (Fig. 5D).The globules obviously consist of cryptocristalline calcite. Their importance for the brachiopod structure is discussed in fossil data.

Winterhalter and Siivola (1967) have run an electron microprobe study of the recent FeMn concretions from the bottom of the Gulf of Bothnia. These also display a rather high 
phosphorus content averaging $3.5 \%$ and phosphorus thus seems to continue to be relatively enriched in the area since the Cambrian (see analyses in Lauren et al. 1978 and Lehtovaara 1982b).

\section{Comparisons of origin}

As far as the general mineralogy and petrology of the sample are concerned, provided the characteristics described are taken into account, the rock is reminiscent of coarser sedimentary rocks from the Söderfjärden basin (Laurén et al. 1978; Lehtovaara 1982b) or those from the bottom of the Bothnian Sea (Thorslund and Axberg 1979). The Olkiluoto sample is, of course, exceptionally fossiliferous but it does not differ in the quality of minerals or diagenesis.

As only a single sample of rock was available here, one can only make the general statement that this rock has no obvious petrological restraints preventing it from being compared with the Lingulid Sandstone in Västergötland and Närke in Sweden (Holm 1901; Martinsson 1974) or the Lükati and especially the Tiskre Beds in Estonia (Öpik 1956). A similar comparison with contemporaneous Scanian formations (Bergström and Ahlberg 1981) is lithologically not so obvious, and, owing to the long distance, the sedimentary environment may well differ.

\section{Boulders 2. and 3.}

These small boulders (Figs. 8 and 12) could only be studied on the surface. Their degree of secondary rusting is more advanced than in the bigger sample. These quartz sandstones are also conglomeratic but not so coarse and fossiliferous as the Olkiluoto sample.

\section{Origin and source}

It should be pointed out that even though a nominal content of glauconite exists in the sandy matrix of the Olkiluoto sample, the content is decidedly lower than that in the phosphoritic rock fragments of the same sample. A similar condition in the Kinnekulle area has been interpreted to mean that the conglomerate in the uppermost Lingulid Sandstone is regressive in origin (Hadding 1929). Yet in that place the conclusions could be drawn from deposits in situ.

It can be added here that, with little effort, the author of this section was able to find boulders of Lower Cambrian sandstone, small as a rule, unfossiliferous to the unaided eye and containing a little glauconite, in almost any of the glaciogenic deposits that he examined in summer 1982. Even so the occurrence of Cambrian boulders was strongly restricted to the southwest of the Jotnian sandstone area in southwestern Finland. The provenance of a majority of the boulders is probably in the Bothnian Sea where large deposits are known to exist (Winterhalter 1972; Thorslund and Axberg 1979). Even though the petrology of sedimentary rocks is bound to vary in such a large area, there is, however, no justification for presuming that also the particular blocks in this study necessarily originated in that sedimentation area and represent its common deposits, as they may come from specific depositionary environments favourable for preserving fossils.

\section{Fossil data}

\section{The boulder 1. found west of Olkiluoto}

The boulder described contains several poorly preserved brachiopod remains. The largest shell fragments, with length c. 8-11 $\mathrm{mm}$ and width c. $6-8 \mathrm{~mm}$, are those of the elongated oval lingulid types (Figs. $3 \mathrm{~A}, \mathrm{~B}, \mathrm{C}$ ). Figure $3 \mathrm{~A}$ illustrates the inner surface of a flat valve with traces of stronger growth 
Fossiliferous boulders of Lower Cambrian phosphoritic sandstone in southwestern Finland
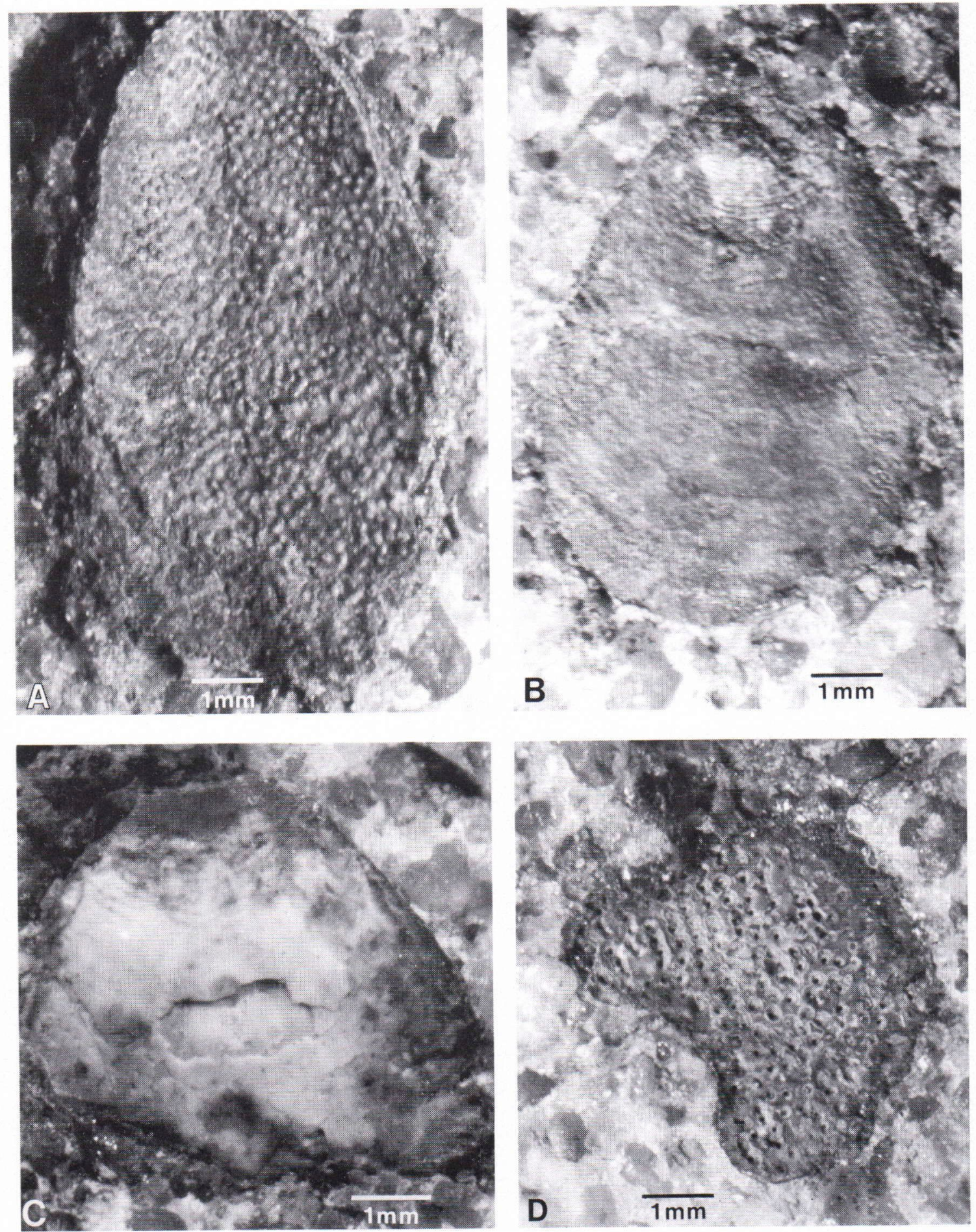

Fig. 3 A, B, C, D Brachiopods remains. A, B, C Lingulid type D? Nisusia. The boulder of Olkiluoto. 


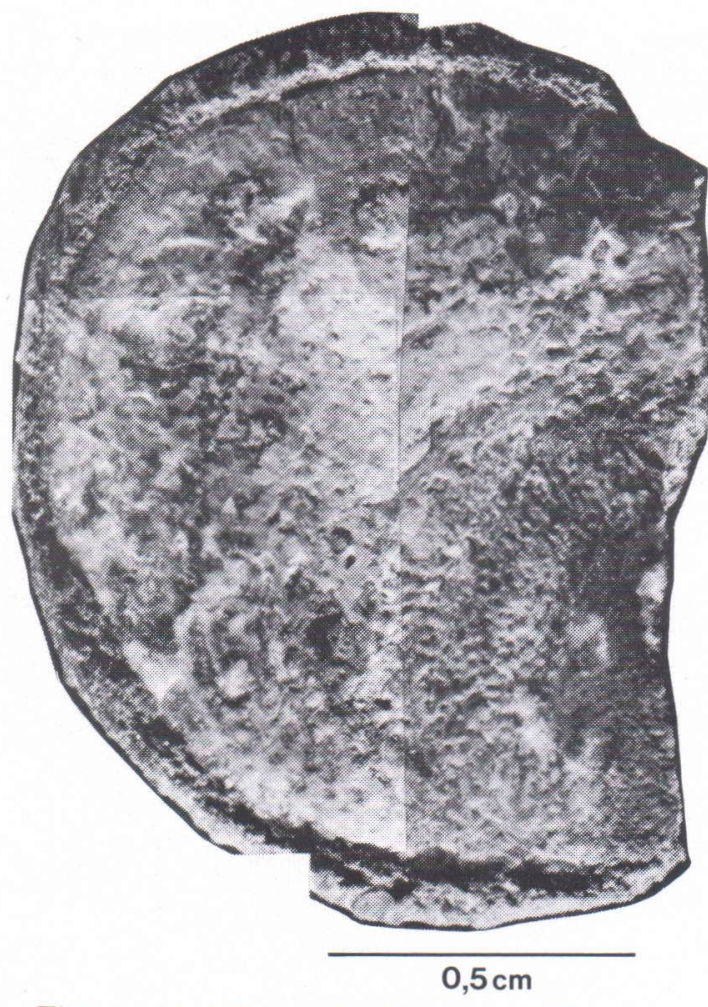

Fig. 4. Obolella sp. the boulder of Olkiluoto.

lines on the valve margin and nodular ornamentation. Figure $3 \mathrm{~B}$ depicts the outer surface of the valve. The structure is due to traces of closely packed, concentric growth lines. Figure $3 \mathrm{C}$ shows the beak of the posterior end of the valve, with its densely spaced concentric lines. The poorly developed radial lines of the inner layer are vaguely visible in the broken part of the valve. The same feature characterized Lingulella Salter described by Williams and Rowell in 1965. Some of the Lingulella forms described by Wiman (1903), mainly from boulders in the northern Baltic area, resemble the best preserved fossils from Olkiluoto reported in the present paper, but the boundary with the genus Obolus is not distinct. The sharp triangular beak characteristic of a typical Lingulella cannot be distinguished in the Olkiluoto form.
A highly concave valve with lines of nodules in association with the radial ridges was also found in the Olkiluoto boulder (Fig. 3 D). The similar structur has Nisusia Walcott genus found from North America. The Nisusia genus has been reported with reservation from the Gislöv formations of the upper Lower Cambrian in southern Sweden (Bergström and Ahlberg 1981).

A worn valve with fairly rounded edges (Fig. 4) was also found in the Olkiluoto boulder. It differs from the former in type and shows vaguely a thick valve edge and random nodular ornamentation. The surface of the valve is flattened and possibly corresponds to the inner surface. A more distinct depression, however, can be seen close to the posterior end of the valve, which is broken and not visible. The preserved portion suggests that the width of the valve exceeds or is equal to its length. The width is c. $15 \mathrm{~mm}$, i.e. somewhat more than the dimensions reported by Kiaer (1917) for Obolella rotundata of the same type. The worn form could not be identified reliably, so the group name obolellid brachiopoda had to be accepted. The same group includes Magnicanalis sp. (Bergström and Ahlberg 1981), which is rather common in the Gislöv formation. In the trilobite zonation the brachiopods Lingulella nathorsti, Magnicanalis sp. or Obolella mobergi and $O$. rotundata correlate with the Holmia kjerulfi-group Zone (Westergård 1929; Troedsson 1917; Bergström and Ahlberg 1981). Moberg (1910) correlated the Holmia kjerulfi zone encountered in Skåne with the Lingulid sandstone facies of Västergötland (Westergård 1929).

Most of the valve remains on Olkiluoto are even less well preserved than those described above, for the outermost valve layers have dissolved and only the flat oval plates remain. Their surface exhibits scattered depressions or pores (Figs. 5 A, B). The wearing of the valve means that the 
Fossiliferous boulders of Lower Cambrian phosphoritic sandstone in southwestern Finland
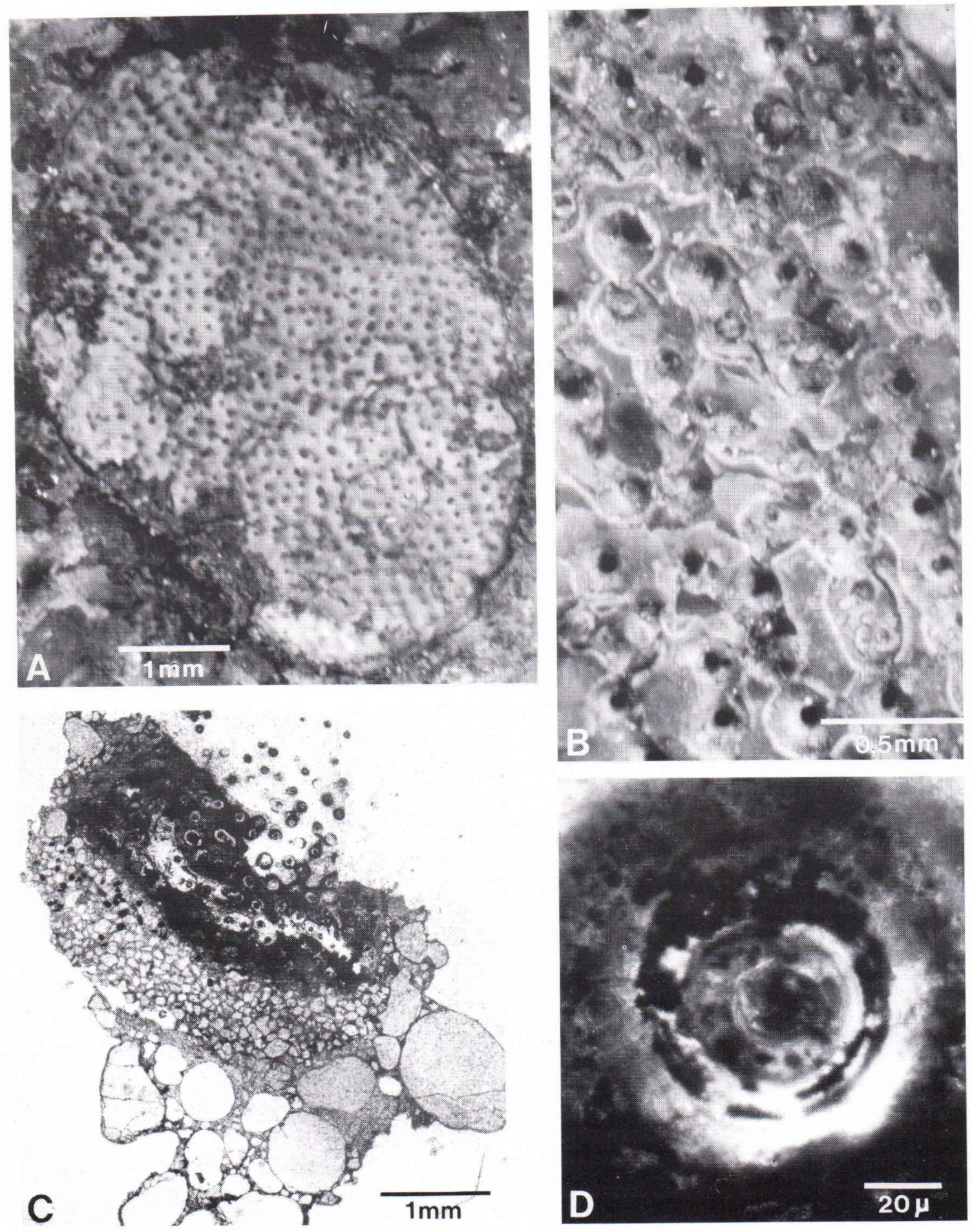

Fig. $5 \mathrm{~A}, \mathrm{~B}, \mathrm{C}$, D Pores of a worn valve of oblolellid/lingulid brachioboda. D. The concentric rings can be seen in the photo in larger size. (C.D thin section crossed nicols) The boulder of Olkiluoto. 
surface structure is accentuated at the site of the smaller pores. The concentric rings that can be seen at the depressions when viewed at higher magnification (Figs. 5 C, D) may correspond to Ca-phosphate and chitinebearing deposits of obolellid/lingulidi brachiopoda. As mentioned above, small nodules occur in places in association with the depressions. The calcite nodules would appear to be an integral part of the valve structure, but Williams and Rowell (1965) point out that the pseudopunctate brachiopods with calcium tubercles do not occur in deposits older than the Ordovician.

The pores of the brachiopod are clearly visible in thin sections as is the fact that the sediment deposited on the valve is finer grained than the sediment in the environment (Fig. 5 C). According to electron microprobe analyses, the valve is predominantly calcium phosphate and thus refers to the class Inarticulata, which also includes the Lower Cambrian genera Mickwitzia, Lingulella and Obolella.

\section{Phosporite-bearing tubes}

The sandstone west of Olkiluoto contains tubular phosphorite-bearing formations whose central part is filled with a rather loose fine-grained sediment. The form varies in type but at its most distinct it is $3 \mathrm{~mm}$ in diameter, and the length of the broken tube or its imprint is $15 \mathrm{~mm}$ (Fig. $6 \mathrm{~A}$ ). The cross-section of the tube in thin section (Fig. 6 B) shows that the phosphorite/ organic matter makes up a rather thin shell. The formation bears a conspicuous resemblance to the Hyolithellus micans fossil encountered in the Lower-Middle Cambrian deposits of southern Scandinavia. Because the material contains irregularshaped phosphorite-bearing fragments of siltstone as well, the likelihood that the formation is of inorganic origin is also discussed.

The tubes may have formed when a finegrained sediment was submitted to rolling action. A partly rolled clay ribbon has been described by Lannerbro (1954) from the Älvdalen Jotnian sandstone. The phosphorite

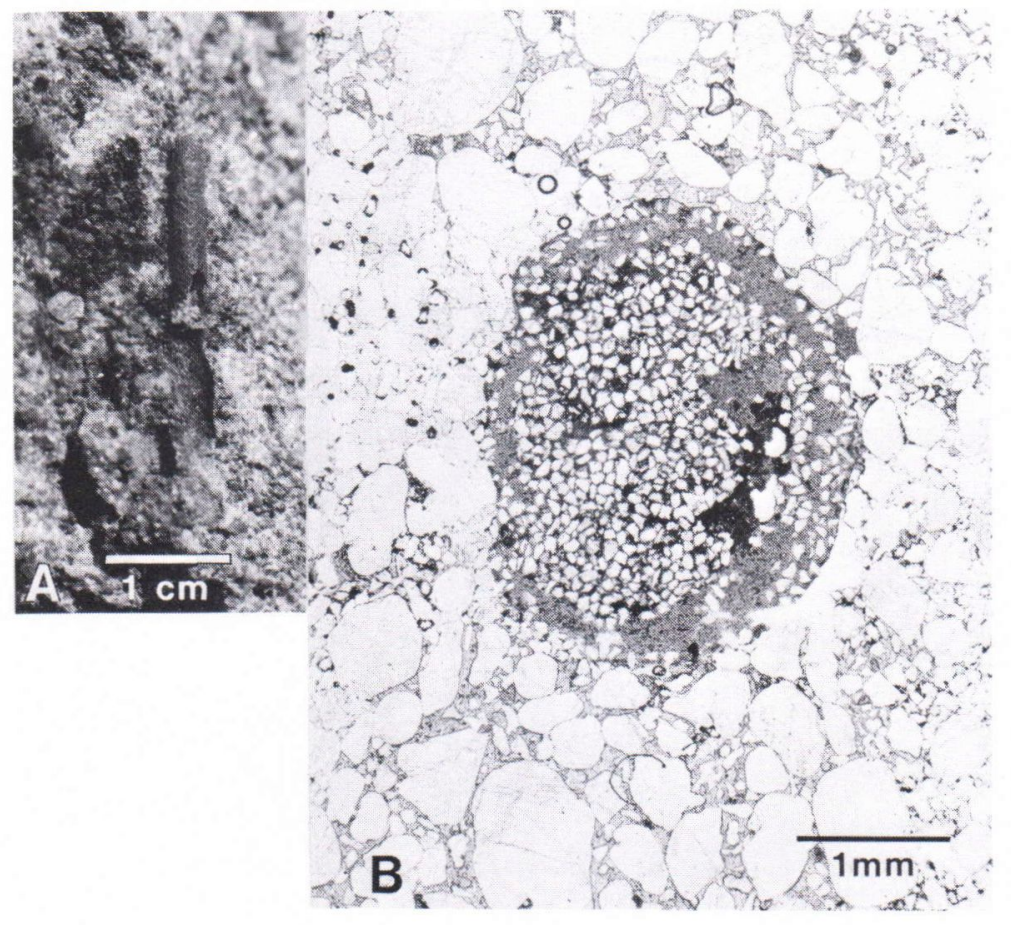

Fig. 6 A Tubular fragment, probably Hyolithellus micans.

Fig. 6 B The cross-section of the tube. The boulder of Olkiluoto. 
tubes in the Olkiluoto sandstone may have been formed as a result of rolling that proceeded still further than that described by Lannerbro. A few rather large rod-like fragments of claystone (Fig. $2 \mathrm{~B}$ ) suggest that the rolling took place before sedimentation. What is more, the surface of the phosphoritebearing claystone fragments is more compact and darker than that of the Hyolithellus type of tube. The crossection (Fig. 6 B) does not, however, show the helicoid grain accumulation that one would expect if the fragment had been submitted to rolling.

Microprobe analyses performed outside the shell, on the shell itself and on the inside of it demonstrate that phosphorus occurs within and on the inside of the shell but that it is lacking outside the shell. Calcium, on the other hand, is present at all three sites, suggesting that the tube could also be of organic origin. According to several studies, Hyolithellus is one of the fossils with phosphate shells. More recent works, however, suggest that the shell of Hyolithellus is composed of numbers of thin layers of organic matter separated by thin films of calcium carbonate. Poulsen (1963) is of the opinion that phosphorus is not a primary constituent of the Hyolithellus shell, but that it may have replaced calcium carbonate later. The soft parts of the organism though did contain primary phosphorus, which has survived as an internal mould (Poulsen 1963).

The tube depicted in Figure $6 \mathrm{~A}$ reveals indistinct transversal lines that can be interpreted as the growth lines of the Hyolithellus. We therefore conclude, with reservations, that Hyolithellus, too, belongs to the fauna of the fossiliferous sandstone boulder of Olkiluoto.

\section{Microfossils}

Only a few large but thin-shelled acritarch microfossils were found in the Olkiluoto boulder. The originally spherical shell is bro- ken and its diameter can only be measured roughly as $200 \mu$. On the basis of the small pores discernible on the surface at intervals of c. $5 \mu$, the acritarch belongs to the genus Tasmanites (Figs. $7 \mathrm{~A}, \mathrm{~B}$ ). It resembles T. tenellus first described by Volkova (1968) from the Lontova formation in Estonia. Later the same species was reported from the Lükati formation as well (Volkova et al. 1979). See also Vidal's (1981) correlation of Scandinavian Cambrian fossil facies with the acritarch genera.

The dating and possible source of the boulder

The brachiopods Lingulella and obolellid types refer to the end of the Lower Cambrian, which corresponds in southern Scandinavia with the Holmia kjerulfi-group Zone (Bergström and Ahlberg 1981) and in the Västergötland area with the Lingulid sandstone facies (Westergård 1929). The possible Hyolithellus could be used for dating even though it also occurs in Middle Cambrian strata.

In the Kinnekulla area Lingulid brachiopoda, and correspondingly the Lingulid sand stone, occur over and are clearly younger than the Mickwitzia sandstone (Holm 1901; Kiaer 1917). Only rarely are Lingulida and Mickwitzia forms encountered together.

The source of the Olkiluoto boulder should be searched for in the direction opposite to glacial flow. One of the likely sources is the Cambrian strata reported by Winterhalter (1972) from the bottom of the Bothnian Sea. Lower Cambrian formations are also encountered in central and northern Sweden, but they are highly improbable source areas. If the Söderfjärden area south of Vaasa (Laurén et al. 1978) were the source, it would have entailed transport from the north, and hence one would expect a greater abundance of boulders closer to the Söderfjärden occurrence. The bottom of the Bothnian Sea is a more likely source. 


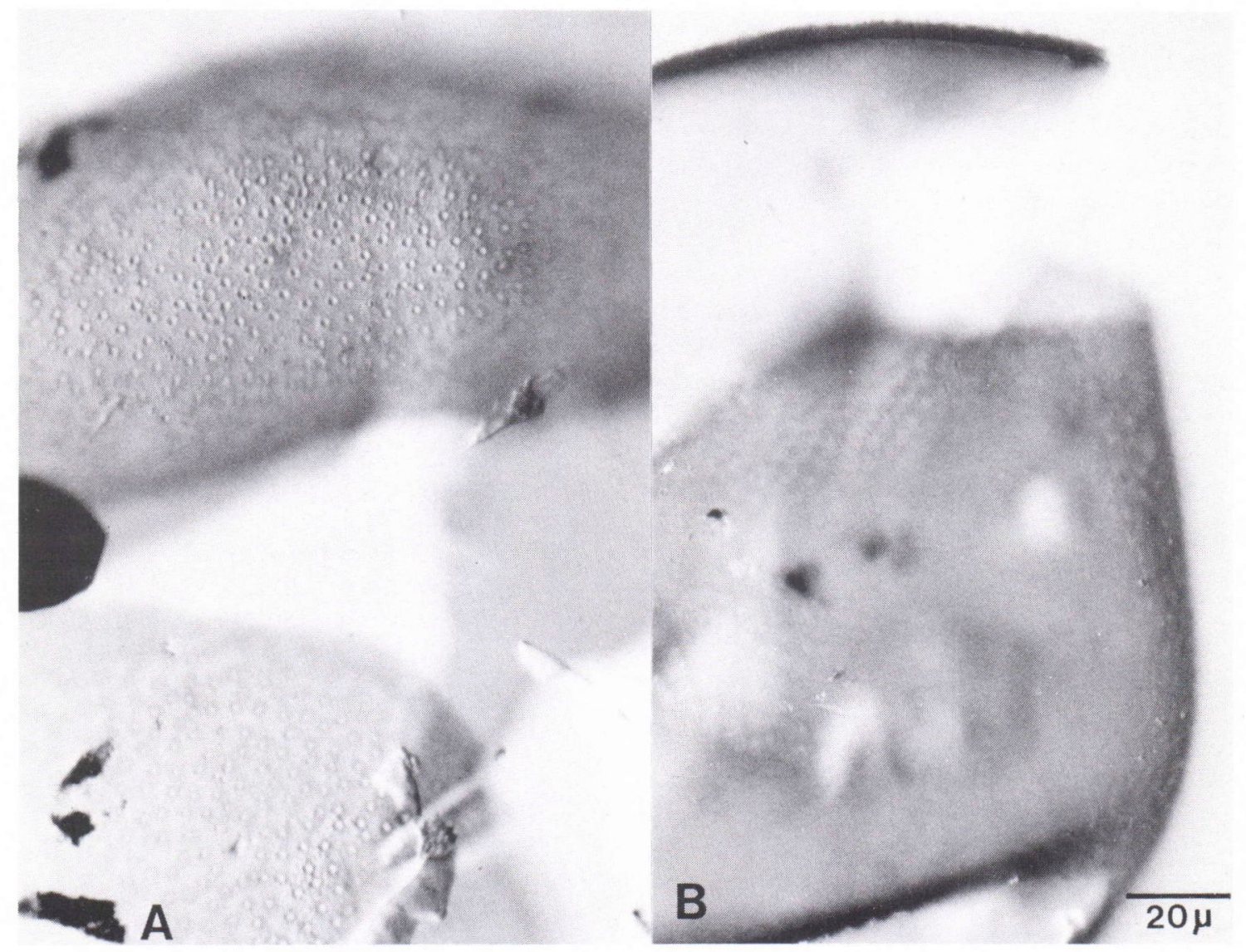

Fig. 7 A, B Tasmanites sp. The boulder of Olkiluoto.

The Olkiluoto boulder has a sandstone groundmass and phosphorite-bearing siltclaystone fragments. It was evidently formed when the clay-silt sediment was still partly plastic. In other words, the clay-silt fragments redeposited during the sedimentation of the sand. The fossils are probably associated with the clay-silt sediment.

The Pyhäjärvi Säkylä boulder 2.

South of Sieravuori on the western side of Lake Pyhäjärvi there is an exceptionally large occurrence of sandstone boulders that has earlier attracted the attention of authors, e.g. Hellaakoski (1930) and Laitakari (1925). The area contains boulders of various sandstone types, principally a pinkish Jotunian sandstone with feldspar (c. 10\%) southwest of the lake. Not so far away, at Kiperjärvenoja, there is another outcrop. Also fairly common (6\%), but lacking fossils, are the quartz-rich sandstones interpreted as Lower Cambrian. The only occurrence with fossils is a rock measuring $15 \mathrm{~cm} \times 10 \mathrm{~cm}$ (Fig. 8), which resembles the phosphorite-bearing Olkiluoto boulder. 
Fig. 8. The phosphoritic boulder of sandstone from the southern side of Sieravuori.

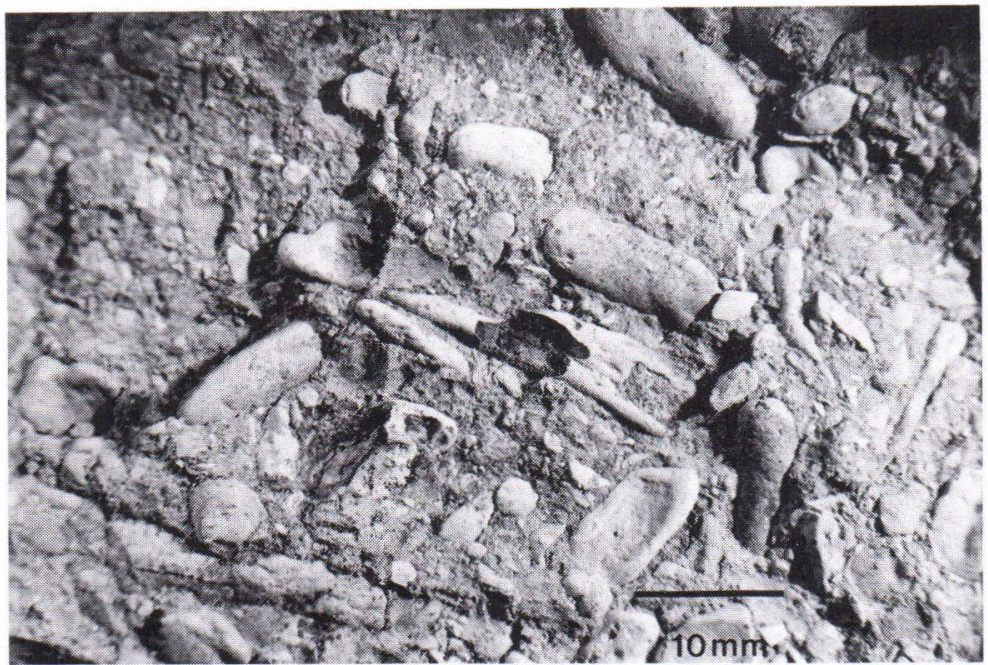

Although the fossil valve fragments in the Säkylä Pyhäjärvi boulder are very worn, we can deduce that they represent the brachiopods common in the Lower Cambrian.

The valve fragment shown in Figure 9 and viewed from inside is very similar in sculpture to the Causea formosa valve described by Wiman (1903) and characterized by ornamentation of nodules and depressions. According to Ager et al. (1965), Causea formosa is a synonym of Mickwitzia monilifera. The sculpture of another valve fragment (Fig. 10) also resembles the sculpture of the outer surface of Mickwitzia; and so the species belongs to this sandstone type. The third valve remnant (Fig. 11) represents a smaller brachiopod. About $6 \mathrm{~mm}$ wide, it is presumably one of the acrotretid brachiopods.

\section{Acritarchs}

Owing to the limited number of samples, the determinations were too few to permit statistically validating. The predominant type, the dark brown fungic cell network, is. possibly of secondary origin. The spiny Baltisphaeridium forms, 35-40 $\mu$ in diameter, typical of the Lower Cambrian are important for dating.

The dating and possible source of the boulder

Although this boulder visually resembles that at Olkiluoto the occurrence of Mickwitzia suggests an older age of Lower Cambrian. The probable source is the bottom of the Bothnian Sea in the direction opposite to glacial flow.

The Northern Viisastenkari boulder 3.

A sandstone boulder resembling that at Olkiluoto was found among the boulders accumulated on the northern shore of the island. The groundmass of the boulder is sandstone, and the proportion of phosphorite-bearing silt-claystone fragments is lower than in the other sandstone boulders. The boulder measures $6 \times 4 \times 2 \mathrm{~cm}$ (Fig. 12).

The remains of the inner part of a brachiopod (Fig. 13) can be seen on the surface of 

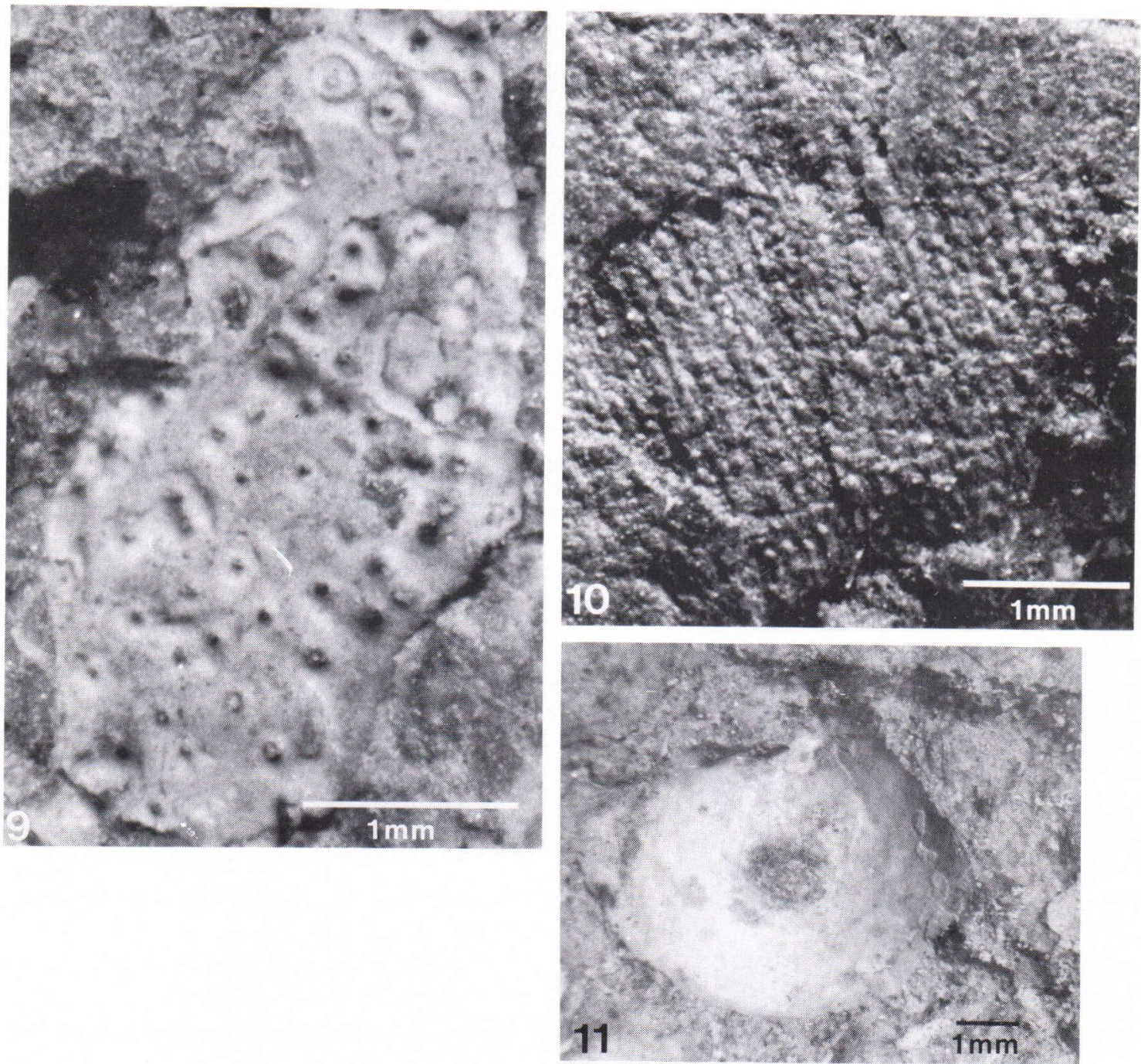

Fig. 9 and 10. Mickwitzia monilifera? Fragments of the boulder from the southern side of Sieravuori. Fig. 11. A small brachiopoda from the southern side of Sieravuori.

the boulder. The form, $15 \mathrm{~mm}$ in diameter, is rounded and of obolellid type. It, too, may be Mickwitzia. The punctate surface structure resembles that of the Olkiluoto type in Figure $3 \mathrm{~A}$. The nodular ornamentation of the smaller fragment shown in Figure 14 resembles the sculpture of Mickwitzia to some extent, but is less dense and more irregular.
The dating and possible source of the boulder

The fossils are so worn that the dating of the boulder is no more than tentative. The Lower Cambrian age is probable, but more accurate correlation with the former two boulder types is not possible. The source of this boulder, too, is considered to be the bottom of the near-by Bothnian Sea. 

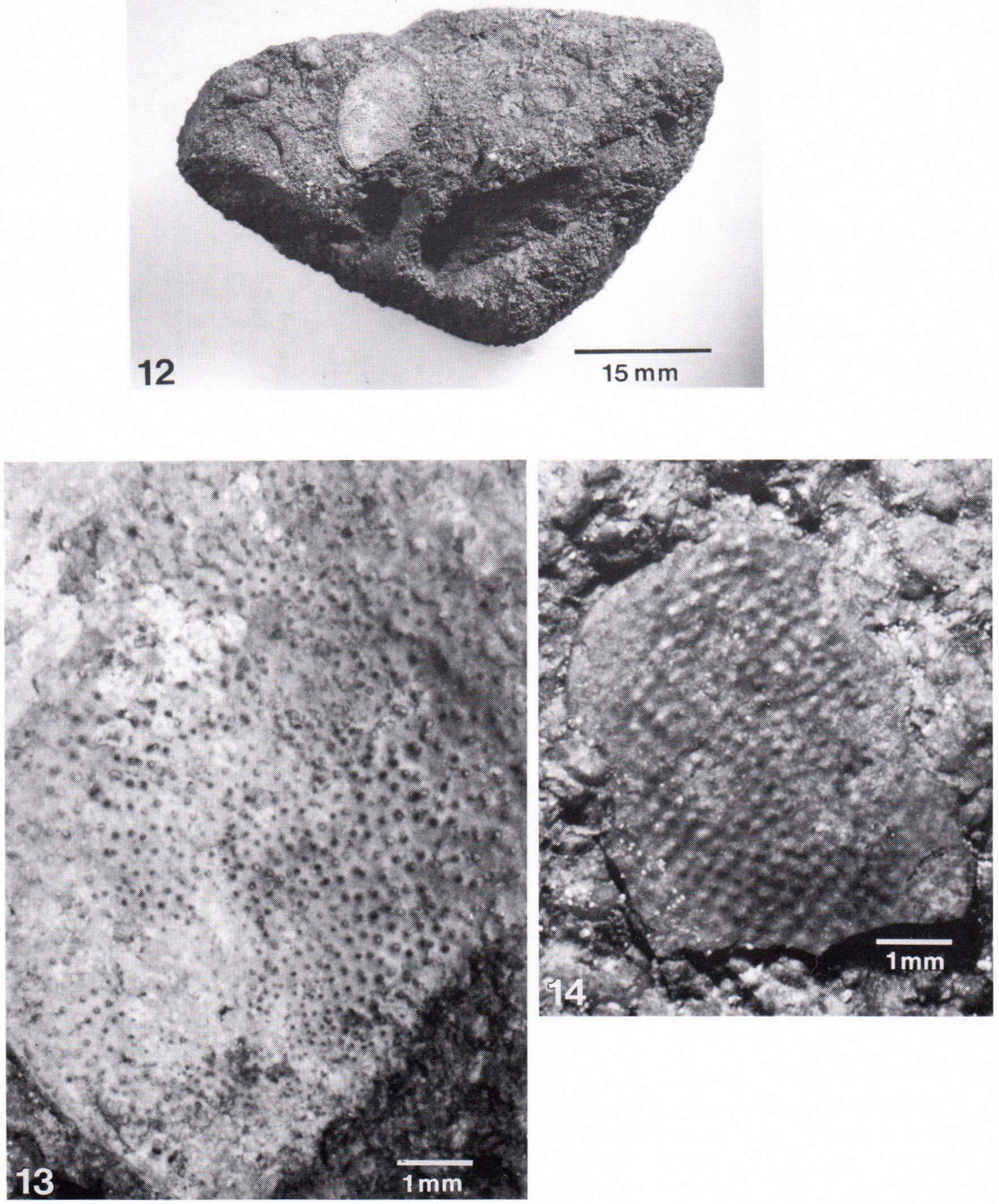

Fig. 12. The phosphoritic boulder from the northern Viisastenkari.

Fig. 13. and 14. Very poorly preserved obolellid type brachiopod remains from the northern Viisastenkari. 
Acknowledgements. The most important material for the present work was obtained with the kind assistance of Mr. Matti Tirronen. Part of the Laitila Pyhäjärvi material was collected by Dr. Ilkka Laitakari, most of the rest by $\mathrm{Mr}$ Kalevi Hokkanen, who also participated in the

\section{References}

Ager, D. V. et al., 1965. Brachiopoda, Systematic Descriptions. In Treatise on Invertebrate Paleontology Part H, ed. R. C. Moore, H 256H 521.

Bergström, J. and Ahlberg, P., 1981. Uppermost Lower Cambrian biostratigraphy in Scania. Geol. Fören. i Stockholm Förhandl. 103, (2) 193-214.

Hadding, A., 1929. The Pre-Quaternary sedimentary rocks of Sweden. III. The Paleozoic and Mesozoic sandstones of Sweden. Medd. Lunds geol. - min. inst. 41.

Hellaakoski, A., 1930. On the transportation of materials in the eskers of Laitila. Fennica 52 (7).

Holm, G., 1901. Kinnekulles berggrud. Sveriges Geol. Unders. Ser. C (172), 1-76.

Kiaer, J., 1917. The Lower Cambrian Holmia fauna at Tomten in Norway. Norske Videnskapsselskapets Skrifter, I. Matem.-Natur videnskap. Kl. 1916 (10), 1-140.

Laitakari, A., 1925. Uber das jotnische Gebiet von Satakunta. Bull. Comm. Géol. Finlande 73, 43 p.

Lannerbro, $R$., 1954. Description of some structures, possibly fossils, in Jotnian sandstone from Mångsbodarna in Dalecarlia. Geol. Fören. i Stockholm Förhandl. 76 (1), 46-50.

Laurén, L., Lehtovaara, J., Boström, R. and Tynni $R$. 1978. On the geology and the Cambrian sediments of the circular depression at Söderfjärden, western Finland. Geol. Surv. Finland Bull. 297, 1-81.

Lehtovaara, J. J., 1982a. Palaeozoic sedimentary rocks in Finland. Ann. Acad. Sci. Fennicae A III, 133, $35 \mathrm{p}$.

Lehtovaara, J. J., 1982b. Stratigraphical section through Lower Cambrian at Söderfjärden, Vaasa, western Finland. Bull. Geol. Soc. Finland $54,35-43$.

Martinsson, A., 1974. The Cambrian of Norden. in Cambrian of the British Isles, Norden and various stages of the study. The microprobe analyses were performed by Mr. Bo Johansson. The thin sections were made by Mr. Turkka Puisto. The manuscript was translated into English by Mrs Gillian Häkli. To all these people we express our sincere thanks.
Spitsbergen, ed. C. H. Holland, John Wiley \& Sons Ltd, pp. 185-283.

Moberg, J. C., 1910. Guide for the principal Silurian districts of Scania (with notes on some localities of Mesozoic beds). Geol. Fören. i Stockholm Förhandl. 32 (1), 1-150.

Öpik, A. A., 1956. Cambrian (Lower Cambrian) of Estonia. XX Congr. Geol. Intern., Mexico. El Sistema Cambrico, su paleogeografia y el problema de su base. Tomo 1, 97-126.

Poulsen, V., 1963. Notes on Hyolithellus Billings, 1871, Class Pogonophora Johannson, 1937. Biologiske Meddelser, Kong. Danske Videnskab. Selskab 23 (12), 1-15.

Simonen, A. and Kouvo, O., 1955. Sandstones in Finland. Bull. Comm. géol. Finlande 168, $57-87$.

Thorslund, P. and Axberg, S., 1979. Geology of the southern Bothnian Sea. Part I. Bull. Geol. Inst. Univ. Uppsala, N.S. 8, 62 p.

Troedsson, G. T., 1917. En skärning i Fågelsångstraktens unde kambrium. Geol. Fören. i Stockholm Förhandl. 39 (5), 603-634.

Vidal, G., 1981. Lower Cambrian acritarch stratigraphy in Scandinavia. Geol. Fören. i Stockholm Förhandl. 103 (2), 183-192.

Volkova, N. A., 1968. Akritarkhi dokembrijskikh inizhnokembrijakikh otlozhenij Estonii. Akad. Nauk SSR, geol. inst. Trudy 188, 8-36. (in Russian).

Volkova, N. A.; Kirjanov, V. V; Piskun, L. V.; Pashkyavichene, L. T.; Yankauskas, T. V., 1979. Microflora in Upper Precambrian and Cambrian paleontology of East-European Platform, ed. B.M. Keller; A.Yu. Rozanov, 4-38. (in Russian).

Westergård, A. H., 1929. A deep boring through Middle and Lower Cambrian strata at Borgholm, Isle of Öland. Sveriges geol. unders. C $355,1-19$.

Williams, A, and Rowell, A, J., 1965. Morphology (Brachiopoda). In: Treatise on invertebrate 
Fossiliferous boulders of Lower Cambrian phosphoritic sandstone in southwestern Finland

Paleontology Part H, ed. R. C. Moore, H. 57155.

Wiman, C., 1903. Studien über das Nordbaltische Silurgebiet. I., Bull. Geol. Inst. Upsala, Vol. $6,12-76$.

Winterhalter, B., 1972., On the geology of the Bothnian Sea, an epeiric sea that has undergone Pleistocene glaciation. Geol. Surv. Finland, Bull. 258, 66 p.
Winterhalter, B. and Siivola, J., 1967. An electron microprobe study of the distribution of iron, manganese, and phosphorus in concretions from the Gulf of Bothnia, northern Baltic Sea. Bull. Comm. Géol. Finlande 229, 161-172.

Manuscript received, March 1, 1983 